\title{
Varia
}

\section{The Commission's Proposal for a Directive on the Fight Against Fraud to the Union's Financial Interests by Means of Criminal Law (COM (2012) 363 final) - An Assessment Based on the Manifesto for a European Criminal Policy}

\author{
Maria Kaiafa-Gbandi ${ }^{\star}$
}

\section{Introduction}

The Commission's proposal for a directive on the fight against fraud to the Union's financial interests (COM (2012) 363 final) is a significant instance in the course of the EU's legislative activity in the field of criminal law. Its significance can be traced back not only to the important legal interest it aspires to protect, but also to the legal basis which is used for the first time since the Lisbon Treaty came into force, as well as to the daring innovation of introducing obligatory minimum penalty thresholds for the Member States. Given the importance and the selfevident interest for the changes in the field of protecting the Union's financial interests, which the proposal is expected to trigger, the following commentary discusses its content on the basis of the Manifesto on a European Criminal Policy (ZIS 2009, pp. 707 et seq, www.crimpol.eu ), shedding light on its merits and demerits with regard to fundamental principles of European Criminal Law. The commentary further aims to offer some concrete proposals for the amelioration of the Commission's provisions.

\section{Assessing the Commission's Proposal on the Basis of Fundamental Principles of European Criminal Law}

1. The requirement of a fundamental legal interest worthy of protection and the legal basis of the proposal

\section{a) Identification of the protected legal interests}

The Commission's proposal aspires to protect first and foremost the Union's financial interests, i.e. its property. In its preamble (para 1) it is stated that this protection should have a holistic character, concerning not only the management of

\footnotetext{
* Maria Kaiafa-Gbandi, is Professor of Criminal Law and International/European Criminal Law at Aristotle University Thessaloniki/Greece. She is currently, as a Fulbright Grantee, Visiting Scholar at the Harvard Law School. The author wishes to express her gratitude to her colleagues of the European Criminal Policy Initiative (ECPI) for their remarks on this assessment.
} 
budget appropriations, but extending to all measures that negatively affect or threaten to affect the Union's assets.

Apart from the EU financial interests however, the proposal aspires to protect additional legal interests that are not mentioned in it. These are: (a) the EU public service and that of its Member States, which are meant to be protected through the provisions regarding passive and active corruption (though only insofar as their violation is connected to a possible negative effect on the Union's financial interests), and (b) the legal interests meant to be protected by the criminalization of money laundering, which is only also relevant here insofar as it concerns the fraud and fraud related criminal acts affecting the EU's financial interests. According to the prevailing view in criminal law doctrine, the legal interest protected by the criminalization of this latter conduct (: money laundering) is the one violated by the act, from which the illegal property has been derived. Consequently, in the case of the Commission's proposal, the criminalization of money laundering refers to the same legal interest as that of punishing fraud and fraud related offences against the EU's financial interests.

Thus, the legal interests aspired to be protected by the Commission's proposal are twofold: the Union's financial interests and the public service of the Union and its Member States.

\section{b) The fundamental character of the protected legal interests}

The protected legal interests by the Commission's proposal are obviously fundamental in terms of their nature for the EU. The Union has been founded as an economic organization of its Member States and even today -despite the widening of its institutional structure- it lays great importance on the economic integration of its Member States. Thus, the protection of its financial interests plays a decisive role, as it contributes to the safeguarding of its existence and to the realization of its goals.

The Union's public service proves to have the same fundamental identity. It is only through an objective and non-pecuniary function of its officials that the EU can realize its goals through its organs and contribute to the prosperity of its citizens. The same is true for the public service of its Member States.

\section{c) Protected legal interests and EU primary law}

The financial interests of the Union (i.e. its property) are actually anchored in the primary EU law. One can recognise the importance of this legal interest today through the provisions of the Lisbon Treaty itself (: Art. 3 para 4 TEU, Art 33, 83 para 2, 86 and 325 TFEU). It is noteworthy that in the Treaty one can find a separate chapter, even though consisting of only one article, that deals with the prevention of and fight against fraud to the Union's financial interests. Additionally, it should not be overlooked that the Union has a special institution for the fight against fraud (OLAF), which has been established for many years now through a Commission decision. 
Concerning the protection of the EU public service one will not find an explicit provision in the Lisbon Treaty. Still, the provisions of the primary EU law, which concern the EU organs and institutions, make their importance for the EU function (e.g. Art. 13-19 TEU, Art. 223 ff. TFEU) evident.

The public service of the EU Member States is obviously not anchored in primary EU law, but this does not mean that it cannot be protected by the Union, as first of all it is a legal interest that belongs to its Member States and secondly, because the method of protecting even "foreign" legal interests is not unknown to national legislators either.

\section{d) Protected legal interests, constitutional tradition of the EU Member States and the EU Charter of Fundamental Rights}

The above-mentioned protected legal interests reconcile with the constitutional traditions of the Member States, because they are classical legal interests, which belong to natural or legal persons (see the property) or society/its citizens (see the public service). As such, they can be protected without causing problems for the Member States' legal orders.

The Union's property, i.e. the property of a supranational organization, which has recently become a legal personality, cannot be treated by the Member States' legal traditions differently from the property of a legal person. As far as it is indisputably an important legal interest for the existence of the Union itself, the Member States have indeed a special obligation to protect it. This is explicitly expressed in the provisions of the EU primary law, which have been mentioned above and in particular, in Article 325 TFEU.

As long as the EU public service is concerned the situation is slightly different, because the Member States normally protect their own public service and not that of foreign States or of international organizations. However, as far as they belong to such organizations this is possible, because of the fundamental character of the legal interest under discussion. On the other hand, one should not forget that in the last few years the different States -in the frame of the fight against corruption- have overtaken, at least to a certain extent, the protection of the public service of other States on the basis of international treaties (see e.g. the Treaty of the Council of Europe for the fight against corruption).

In the EU Charter of fundamental rights, obviously, only such fundamental rights that belong to natural persons and which are protected, mainly against the State, are recognised. Amongst the above mentioned legal interests, only the EU property could claim protection on the basis of the Charter, as bearers of financial interests can be natural persons as well. The public service -as a social legal interest-cannot claim protection thereupon. 


\section{e) The harmfulness of the proscribed conducts}

The proscribed conduct against the Union's financial interests (Art. 3, Art. 4 para 1 and 4) is especially harmful to the society, because such frauds and the related illegal activities pose a serious threat, which can be proved on the basis of empirical data (COM (2012) 363 final, P. 1) and does not allow the Union to achieve its goals.

The harmfulness of the conducts proscribed as far as the other legal interests are concerned, is only of interest in this proposal in so far as it might lead to the violation of the financial interests of the EU.

The special social harmfulness of the corruptive conduct (Art. 4 para 3) is obvious, because it violates the objective and non-pecuniary function of the public service. This social harmfulness, however, is present irrespective of whether such conduct is undertaken as a means of fraud affecting the EU's financial interests or not.

The autonomous social harmfulness of the conduct proscribed as money laundering is, on the other hand, not evident. Rather, it represents a second chance for the penal repression mechanisms to reveal and prosecute the criminal act from which the illegal property has been derived.

\section{f) A provisional conclusion}

The Commission has in its current proposal overtaken a well known method, which can be traced back to the PIF Convention, to the Corpus Juris project and to its old proposal for a directive on the criminal protection of the Community's financial interests of 2001. According to this method, the protection of the EU's financial interests should be achieved through an additional criminalization of conducts that as such violate mainly other legal interests, although they appear to be in a concrete case connected to the damage or the possibility of damaging the Union's financial interests. This choice has to be criticized, because it actually creates a restricted special part of criminal law exclusively for the protection of the EU's financial interests. It is self evident though that there is no sense in criminalizing the corruption of public officials only in connection with the relevant fraudulent acts that violate the EU's financial interests, because corruption as a conduct bears wrongfulness per se. When such conduct is related to fraud against the Union's property, one simply has to deal with the matter of concurrence of different offences that occurs in these cases.

Apart from this, such a method is no longer necessary nowadays, because the Union already has a Treaty (26.5.1997) for the fight against corruption of its officials as well as of those of its Member States.

The same is true as far as money laundering is concerned. In the meantime, money laundering is a consecutive criminal act attached to many other offences and many EU legal instruments that regulate this field already exist, so that new EU 
intervention in order to proscribe money laundering exclusively with regard to fraudulent conduct against the EU's financial interests has no meaning.

Thus it would be wise for the EU in both cases (: corruption and money laundering) just to make adjustments to its existing legal instruments for these two fields, in order to bring the protection up to the desired level, in case this is not already satisfying in view of acts that are related to damages of the Union's financial interests.

Last but not least, striking corruption and money laundering off the list of fraud related offences is imperative for an additional important reason. The Commission's proposal has chosen as a legal basis for this directive Article 325 para 4 TFEU. However, this provision acknowledges the EU competence for criminal law measures only with regard to the prevention of and the fight against fraud affecting the financial interests of the Union and not in respect of other offences that violate mainly other legal interests (compare with regard to the appropriate legal basis the document 15309/12 (October 22nd 2012) of the Council's Legal Service). The Commission's opinion that "The term fraud must in this context be understood in a broad sense, including also certain fraud related criminal offences" (COM (2012) 363 final, p. 6) is not convincing, not only because there is no criteria to which extend such a broad sense applies, but also because Article 325 TFEU, acknowledging special competence to the EU for the fight against fraud to its financial interests, should be interpreted in a somewhat narrow rather than a wide sense, as is the case with all special rules. Seeking a source of competence in Article 325 para 1 TFEU as a legal basis for fraud related offences would not be possible either, because the only provision which can serve as a legal basis of the EU competence for criminal law measures is para 4 of Article 325 TFEU. Criminal law measures for fraud related offences, as those proscribed in Article 4 paras 2 and 3 of the Commission's proposal, could be based only on the competence acknowledged to the European Union by Article 83 para 1 TFEU.

\section{On the ultima ratio principle}

\section{a) Alternatives to criminal sanctions protection mechanisms}

The Commission recognises in its proposal that there are indeed alternatives to criminal law protection mechanisms available for the Union's financial interests. This is why it stresses that "criminal law in the Member States should continue to complement the protection of the Union's financial interests under administrative and civil law for the most serious types of fraud related conduct in this field, whilst avoiding inconsistencies, both within and among these areas of law" (preamble para 2).

However, the general recognition of a complementary character for criminal law's function in the respective field does not mean per se that this character is actually safeguarded by the proposed provisions. The Commission itself reveals in its proposal that the legal instrument proposed "extends the types of some fraud related 
offences, introduces minimum sanctions and harmonizes statutory limitations (of the Member States)" (COM (2012) 363 final, p. 6). All these elements are obviously choices of expanding criminal law, whilst the necessity for such provisions is, as we will see below, not further elaborated.

\section{b) Inadequate effectiveness of alternative measures in practice?}

The Commission's starting point is that criminalization of certain conducts is necessary as complementary to administrative or civil law measures. This is of course true for the protection of such vital legal interests as the Union's financial interests. Still, it would be necessary for the proposal to demonstrate why exactly the existent administrative or civil law measures in the fields that should be covered by criminal law are of inadequate effectiveness in practice. This deficiency may be explicable due to the existing EU aquis in this area, which already includes criminal law rules for fraud, corruption and money laundering (see COM (2012) 363 final, p. 2). However, the Commission should have demonstrated, at least for all new forms of criminalization introduced by its current proposal, the necessity of these rules in comparison to the existing administrative or civil law measures.

It is true that the Commission tries to explain in its proposal the reasons for undertaking a new harmonization of the Member States' criminal law provisions in the field, in comparison to the existing status. Whether we need new criminal law provisions instead of administrative or civil law measures is a different question though, and a different one to whether we are to change the existing criminal law rules seeking more effectiveness. Both questions are related to the matter of whether criminal law is used in a specific case as a last resort (ultima ratio principle). If administrative measures are sufficient, no criminal law provisions are needed. And if existent criminal law measures are sufficient, then no new criminal law provisions can be justified. This is why both these questions need a separate answer.

\section{c) Explicit justification for resorting to criminal law measures}

On the other hand, one has to stress the importance of the fact that the Commission avoids the mistake made in all proposals of new directives, which were introduced after the Lisbon Treaty, where it actually referred in general terms to 4 different policy options (which were identical in every proposal: Policy option (1): Status Quo / No new EU action, Policy option (2): Development of a programme to strengthen the efforts in counter attacks against information systems by means of non-legislative measures, Policy option (3): Targeted update of the rules of the Framework Decision (new Directive replacing the current Framework Decision, Policy option (4): Introduction of comprehensive EU legislation against cybercrime), and then named its preference for one of them with no further justification.

However, trying to explain why resorting to criminal law with a new legal instrument on the fight against fraud affecting the Union's financial interests is necessary, the Commission attaches sole importance to the diverging rules that 
Member States have adopted and the consequently often diverging levels of protection within their national legal systems (COM (2012) 363 final p. 2). According to the Commission, this state of affairs shows that there is no equivalent protection of the Union's financial interests, and that measures against fraud have not reached the necessary level of deterrence (COM (2012) 363 final p. 2). As an example, the fact is used that with respect to fraud the Member States have included definitions of this crime in many different forms of legislation, ranging from general criminal law, which may include specific or generic offences, to criminal tax codes, as well as the divergence that can be noted with respect to the levels of sanctions, which are applicable to these forms of crime in the different Member States (COM (2012) 363 final, p. 2). However, even diverging levels of protection do not necessarily mean that there is need for an intervention, i. e. for bringing these levels to the same stage. Under the perspective of the ultima ratio principle the decisive question is not whether such diversions have a negative impact on the effectiveness of the Union's policies to protect its financial interests (COM (2012) 363 final, p.3), but whether more criminal law (due to new conduct that should be criminalized or higher levels of punishments through the introduction of minimum levels for them) can be justified as a last resort for the specific acts and the relevant punishments for them. This question cannot be answered with a general statement that refers to diverging levels of protection in the different Member States. On the other hand, it is worth while mentioning that the Lisbon Treaty itself obliges Member States to introduce the same level of protection regarding the Union's financial interests compared to the one available for their own (Article 325 para 2 TFEU) and not a level of protection that would be the same all over the Union.

In other words, the question that is related to the ultima ratio principle does not refer to the necessity of certain criminal law provisions in order to ensure the effectiveness of the Union's policies to protect its financial interests (cfd. COM (2012) 363 final p. 3), but it refers to the impossibility to find milder means in order to tackle the problem. Thus, it may very well be that removing diverging levels of criminal law protection could make the Union's policies in the field more effective, but this does not mean that such an expansion of criminal law is also justified in view of its use as a last resort.

\section{d) The proscribed types of conduct under the ultima ratio perspective}

Reviewing whether the proscribed types of conduct in the Commission's proposal indeed call for criminal sanctions as a last resort, one could make the following remarks:

By fraud affecting the Union's financial interests (art. 3) the problem lies mainly in the broad sense, in which the punishable conduct is described insomuch as it refers to an omission. The proposal calls the Member States to punish "any (act or) omission relating to the use or presentation of false, incorrect or incomplete statements, etc, which has as its effect the misappropriation or wrongful retention of funds from the Union budget, or any such (act or) omission relating to the misapplication of 
liabilities or expenditure for purposes other than those for which they were granted". According to this provision the punishable omission in the two forms of conduct described in Art. 3 doesn't need to be an omission violating a specific obligation. Thus practically any person, who might even have no special obligation to present a correct document, i. e. someone who is not even the responsible person for such a conduct in the frame of a company, could make oneself punishable for fraud affecting the Union's financial interests if he/she knows about the planned presentation of an incorrect document, can report and stop it and doesn't do so with the result that the EU suffers a damage of its financial interests, due to a misappropriation of funding given to the specific company. Such criminal liability for an omission resulting in financial damage irrespective of any violation of a specific obligation to act and prevent the undesired result goes too far, because in the European legal tradition not every person can be held as a guarantor for the legal interests of another person or a legal entity and consequently be liable for their violation by someone else. This can be very well illustrated in the differentiation made between the criminal liability of a simple passenger for not helping a wounded child who lies in the street, compared to that of the child's mother. If we were to punish any omission like an act, with no additional prerequisites, especially in cases where the result cannot be caused without another person's act, then criminal law would seize control of our everyday life. Thus, the description of the punishable conduct referring to fraud affecting the Union's financial interests should be improved as long as Art. 3 paras (a) and (b) (i) and (ii) are concerned, although the existing PIF Convention is using the same wording with regard to fraudulent conduct in the form of omissions. In this respect, the Commission's proposal can be used as a tool for improving the existing status, as this is in fact the case with other provisions of the proposal as well (see Article 3 with regard to the intention and further on in this text under the principle of guilt).

Concerning the fraud related offences, one should highlight first of all that there are provisions in the Commission's proposal which can be held as characteristic examples for respecting the ultima ratio principle.

The Commission's choice to punish corruption only with regard to future actions of a public official, and not in respect of those that have already taken place, is such an example, because in these latter cases the connection between the bribe and its influence on the public service's functioning (the connection "do ut des") can be very easily questioned.

On the other hand, Art. 7 para 2 concerning minor offences, irrespective of their concrete character as fraud or fraud related offences, which involve damage or advantages of less than 10,000 Euros and that are not accompanied by particularly serious circumstances, for which Member States may instead provide alternatives other than criminal penalties, serves also as a characteristic example of safeguarding the ultima ratio principle. Minor wrongfulness in the field of economic crime depends on the level of the economic damage in which the conduct results and thus one should always keep in mind that for such cases criminal law might very well not 
be needed as a last resort, because alternative milder means in the field of administrative or civil law can be easily found.

Unfortunately, a violation of the ultima ratio principle is discernible, however, in the fraud related offence of Art. 4 para 1, which refers to public procurements or grant procedures. The violation of the principle is based on the fact that the proscribed conduct is not bound as such (i.e. in terms of its objective elements) to any kind of a possible danger for a circumvention or skewing of the eligibility, exclusion, selection or award criteria of a public procurement or a grant, arising from the suitability of the conduct itself. The choice made by the Commission expands criminal liability with no justification even to cases where the proscribed conduct could not lead objectively to the circumvention or the skewing of the procedure, because the concrete suitability of the proscribed conduct for such a result is not an element of the actus reus. Thus, the criminal liability referred to here is a situation that lies far ahead of any possible damage of the Union's financial interests and is actually solely based on the perpetrator's intention of circumventing or skewing the criteria of a certain process. This combination of a proscribed conduct that does not yet create - under any possible conception- a kind of danger for the protected legal interest is of course a sign for an over expanding criminal law, which does not respect the ultima ratio principle and places the centre of punishability on criminal intention, which is not even relevant to the violation of the legal interest that it is the aspiration to protect.

\section{On the principles of guilt and proportionality}

\section{a) The principle of guilt and mens rea elements}

All the proscribed conducts in the Commission's proposal refer to intentional acts or omissions. Thus the principle of guilt is, as far as this general requirement is concerned, safeguarded.

A further relevant progress to the existing status should also be stressed. In the proposal, one no longer finds the well known phrase-since the PIF Convention (Art. 1 para 4)- that "the intentional character of the punishable act or omission ......... may be inferred from objective, factual circumstances". Through such an automatic conclusion the guilt principle can be easily circumvented and thus one has to acknowledge the particularly positive step made by the Commission towards safeguarding the guilt principle by erasing the relevant phrase (see the relevant proposal for other EU legal acts already in ECPI, Manifesto on a European Criminal Policy, ZIS 2009, 711). However, these positive findings do not mean that the guilt principle is safeguarded for the specific offences that the proposal includes, i. e. with regard to the question whether their type and gravity corresponds to the individual guilt. 


\section{b) Introducing binding minimum thresholds of penalties and the prin- ciples of guilt and proportionality}

For the first time in the proposed directive, we experience the application of minimum levels of sanctions not only for the maximum but also for the minimum threshold of the penalties that are to be threatened by the national legislators. Such a choice can very easily disturb the coherence of the individual national legal systems, as will be discussed below, but it can also create serious problems with regard to the proportionality principle. If the minimum threshold of a penalty is set too high, the proportionality principle is unavoidably violated. This is not inevitably so in the case of the maximum threshold of penalties, as the judge still has the possibility not to reach it. On the contrary the judgement of a concrete case cannot circumvent the minimum penalty threshold of a certain criminal law provision, unless the respective legal order is familiar with an institution of reforming this threshold in cases, for example, of mitigating circumstances, which of course are not always available.

The Commission's choice is also disputable under the perspective of the nature of a directive as a European legal instrument. By using a method of defining both the minimum and the maximum threshold of the minimum penalties which are to be proscribed by the national legislators, the Union does not actually leave any free space for the Member States to define the means of reaching the directive's goals, when incorporating the European legislative act into their national legal systems. In other words, the Commission's proposal actually tends to take on the characteristics of a regulation rather than a directive, because as far as the penalties for certain offences are concerned there is almost nothing left for the national legislators to define.

On the other hand, it is also disputable as to whether the method chosen by the Commission is compatible with the assimilation principle ruling on the protection of the Union's financial interests according to the Lisbon Treaty (Art. 325 para 2 TFEU). The Member States are obliged to protect the Union's financial interests by taking the same measures to counter fraud as they take against fraud regarding their own financial interests. Introducing European minimum levels for the minimum threshold of the penalties for fraud and fraud related offences that affect the Union's financial interests may very well lead to a higher protection of the Union's interests towards those of the Member States. This is a consequence that exceeds the manifest intention of the Union's primary law.

Apart from this, if one recalls that the Union has not until now set any obligatory level for the minimum thresholds of penalties as far as the protection of personal legal interests (e.g. life, freedom, sexual integrity of children etc.) is concerned, one may assume that this is a sign of a non justifiable discrepancy, because according to a basic stance of the European legal tradition, personal legal interests are normally held in greater importance than those that are non personal/material (e.g. property).

If one leaves aside the above mentioned general problems, which arise due to the Commission's new method for setting penalties, and focuses on the specific provi- 
sions of the proposed directive with regard to penalties and the guilt or proportionality principle, one can arrive at both positive and negative conclusions.

First of all, and in a positive light, we should evaluate the Commission's choice to leave the exact level of penalties for cases which involve an advantage or damage of less than 30,000 Euros to the discretion of the Member States, under the general provision, of course, that the penalties for fraud and fraud related crimes have to be effective, proportionate and dissuasive, including fines and imprisonment.

However, with regard to penalties, the Commission differentiates among the fraud related offences in a way that is obviously problematic. A differentiation is justified and has to be made, if it is based on the distinct wrongfulness and guilt that accompanies the respective offences. As such it is difficult to comprehend why the European legislator has chosen to threaten the fraud related offence of Art. 8 para 1, first phrase, which refers to a certain conduct in the frame of public procurements or grant procedures with the aim of circumventing or skewing the application of eligibility, exclusion, selection or award criteria, with the same threshold of penalties as that of fraud affecting the Union's financial interests. The latter is an offence resulting in damage of the Union's property, while the former is one that can just endanger those interests. Punishing with the same level of penalties offences with differing grades of wrongfulness (: harm and the possibility of such harm), violates the proportionality principle and consequently the principle of guilt.

On the other hand, equally (if not even more) problematic is the second phrase of Art. 8 para 1, which defines the level of penalties for money laundering and corruption. These two offences should according to the Commission be punished with even higher penalties than those for fraud, as the Commission has set the same minimum and maximum threshold for them as for that attached to fraud (6 months and 5 years respectively), albeit starting from a lower level of the advantage or damage involved, i. e. when the latter is at least 30,000 Euros (and not 100,000 Euros). With regard to corruption, such a choice could be understood as here there is an additional legal interest involved (: the Union's public service and that of its Member States). This is not, however, the case for money laundering. The legal interest violated through money laundering is the same as that of the former basic act, the product of which has been laundered. Thus, money laundering that leads to fraud in terms of the Union's financial interests cannot be punished with an even higher level of penalties than that which has been determined for fraud, as in this case the legal interest protected is not only the same, but it has already been additionally damaged through fraud as described in Art. 3.

As far as the guilt and proportionality principles are concerned, the important provision of Art. 7 para 4 should be highlighted, according to which Member States are to ensure that sanctions of another nature, that cannot be equated to criminal penalties, and which are already imposed on the same person for the same conduct, can be taken into account when sentencing that person for a criminal offence referred to in the Commission's proposal. Despite the distinct nature and goals served by the different kinds of sanctions, the proportionality principle is obviously 
better served when the judge can take into consideration the fact of a multiple sanctioning for the same conduct, especially in a field where administrative sanctions normally refer to the same conducts that are punished through criminal provisions as well.

\section{c) The real reasons for the choices made in the field of penalties}

The European legislator deals with the question of whether his proposed minimum levels of sanctions are appropriate by taking into consideration the guilt of the individual in the proposal's explanatory thoughts (see preamble para 12: "In order to protect the Union's financial interests equivalently through measures which should act as a deterrent throughout the Union, member States should further foresee certain minimum types and levels of sanctions when the criminal offences defined in this directive are committed. The levels of sanctions should not go beyond what is proportionate for the offences and a threshold expressed in money, under which criminalisation is not necessary, should therefore be introduced"). It is interesting that the Commission's thoughts in the preamble reveal the real reasons for the choices made.

First of all, the main concern seems to be achieving deterrence throughout the Union by means of an equivalent protection in all Member States (see preamble para 12 above and para 14: "The sanctions for natural persons in more serious cases should foresee imprisonment ranges. These serious cases should be defined by referring to a certain minimum overall damage, expressed in money, which must have been caused by the criminal behaviour to the Union's and, possibly, other budget[s]. The introduction of minimum maximum imprisonment ranges is necessary in order to guarantee that the Union's financial interests are given an equivalent protection throughout Europe"). However, introducing minimum maximum imprisonment ranges to a certain overall damage, expressed in money, does not make, as has already been argued above, the penalties proportionate in themselves. The principle of proportionality is a fundamental European legal principle. Thus it should be examined in a holistic way, i. e. horizontally (: in respect of different offences on a European level), vertically (: in respect of similar offences in the Member States) and above all stricto sensu, in other words with regard to every introduced minimum/maximum level of penalty in relation to the offence it is attached to. Such control helps to avoid violations of the proportionality and guilt principles such as those described above.

On the other hand, the Commission relates the choices made, and especially that of the minimum level of penalties introduced (6 months), with the possibility of issuing a European Arrest Warrant for such cases (see preamble para 14: "The minimum sanction of six months ensures that a European Arrest Warrant can be issued and executed for the offences listed in Article 2 of the Framework Decision on the European Arrest Warrant, thus ensuring that judicial and law enforcement cooperation will be as efficient as possible"). However setting the range of penalties on the basis of a possibility for applying a procedural tool not only circumvents the proportionality and guilt principles, but actually overturns the relationship between 
substantial and procedural criminal law. The latter is there to ensure the application of the former and can never become a criterion for the substantive criminal law rules. Thus setting the ranges of penalties cannot take into account whether this would facilitate the issuance of the EAW. On the contrary, the way of thinking should be exactly the opposite, i. e. the EAW should only be issued in cases of offences which prove to be -on the basis of other substantial criteria- so serious that they allow the issuance of such a severe procedural tool.

Last but not least two remarks are in order here: first, one should keep in mind that minimum levels of penalties, like the one set by the Commission (6 months) for certain offences do not lead to a consistent punishment of the same conduct in all Member States, because a penalty of 6 months in Germany, for example, has a completely different dimension to a penalty of 6 months in Bulgaria or Greece; secondly, it should be mentioned that the way the Commission refers to the proportionality principle is general and insufficient compared to its importance in the framework of the European law. Apart from the above mentioned paragraphs of the preamble one finds only one phrase in the explanatory thoughts of the proposal which makes reference to it, but this unfortunately fails to give any specific argument for supporting the principle. According to the Commission: "It has carefully been ensured that these measures do not go beyond what is necessary to achieve this objective and are thus proportionate" (COM (2012) 363 final, p. 8). Recalling the arguments presented above one finds out that there are plenty of reasons to argue on the contrary.

\section{On the principle of legality}

\section{a) The lex certa requirement}

As far as fraud affecting the Union's financial interests (Art. 3) is concerned, one could argue that the way the punishable conduct is described is not in line with the lex certa requirement, i. e. it does not allow the described conduct to emanate from the proposed directive itself and thus it does not make clear on the one hand what national legislators are expected to punish whilst on the other hand, which conduct can make citizens criminally liable according to the Union. Specifically, the Commission's proposal defines fraud in respect of expenditure or revenue, any act or omission relating to: (i) the use or presentation of false, incorrect or incomplete statements or documents, which has as its effect either the misappropriation or wrongful retention of funds from the Union budget..... or the illegal diminution of the resources of it". In this way, though it is unclear which acts or omissions the European legislator is referring to, because relating to the use or presentation of false statements or documents may encompass many different acts or omissions, such as supporting them, facilitating them, or even preparing them, for example. Apart from causing problems in respect of the legality principle, this can also result in an over broadening of the criminalization of fraud affecting the Union's financial interests. 
On the other hand, with regard to fraud related criminal offences affecting the Union's financial interests, similar problems arise through the description of corruption. The Commission's proposal does not include expressis verbis in the description of corruption the bribery behaviour, which is meant to lead an official to act or refrain from acting against his duties. This deficiency is not justified as according to the Commission's proposal, acts of bribery are punished even for the case of an official acting in accordance with his duty. On the other hand, one could not argue that the wording of Art. 4 para 3, which refers to a public official acting "in the exercise of his functions in a way which damages or is likely to damage the Union's financial interests", solves the problem by covering the above mentioned deficiency. Acting in a way which damages the Union's financial interests does not necessarily involve a conduct that is "against the duties of an official". By not regulating this case, the directive's description for the offence of corruption does not make the relevant conduct foreseeable from its own wording and, as such, it is not in line with the lex certa requirement.

\section{b) National legislators and the implementation of the prescriptions imposed by the European legislative act}

For the cases mentioned above, the national legislators do not have the possibility to implement the provisions of the proposal without doubts regarding their alignment with the European law. The vagueness of the proposal's wording by fraud and its deficiency for covering characteristic cases of corruption do not allow national legislators to understand what exactly the European legislator meant to define as a criminal offence in the respective fields. Under these conditions and for the purpose of avoiding contravening the Union's choices, national legislators normally chose the "safe" method of just "copying" the Union's notion of an offence, reproducing the same problem on a national level, and do not usually follow their own way for defining it, because of the relevant risk of not being in conformity with the European legislative act, which they are supposed to transfer over into their national legal order. Thus, the European legislator should try to solve the problems related to the principle of legality detected in the Commission's proposal.

\section{On the principle of subsidiarity}

\section{a) Insufficiency of criminal law measures at Member State level?}

As far as the protection of the Union's financial interests is concerned, the TFEU abides by the already well known assimilation principle (Article 325 para 2), according to which Member States are obliged to protect the Union's financial interests in the same way they protect their own. This choice allows actually for a different level of protection in the different Member States. It has to be read, however, systematically in combination with other articles of the Treaty, such as Articles 325 para 4 and 83 para 2 TFEU, for example. The combination of the latter makes clear that as long as harmonization of criminal law measures can be adopted in fields of different 
EU policies, for which the support of criminal law is inevitable, this cannot be denied for the protection of the Union's financial interests. On the other hand, the actual content of Article 325 para 4 TFEU, as it stands today and in comparison to the past, shows that the Treaty itself intended to make it possible for the Union to intervene for the protection of its financial interests even with criminal law measures.

This institutional framework, which allows for the Union's intervention combined with the unsatisfactory situation that is described in the explanatory report of the Commission's proposal, referring to the diverging levels of protection of the Union's financial interests within the different national legal systems of the EU's Member States, makes the Union's choice for a directive striving to harmonize the criminal legislation of the Member States in this field understandable. From a European citizen's point of view, one could also argue that as far as one is dealing with the same legal interest that belongs to the EU itself, it is a matter of equality for the peoples of Europe to at least be treated in an equivalent way when they harm or endanger the Union's property. Apart from the above arguments, harmonized content of fraud affecting the Union's financial interests could also facilitate the police and judicial cooperation in the fields of research and prosecuting measures against fraudulent conducts that bear a transnational character.

This general estimation regarding the Commission's proposal being in line with the subsidiarity principle does not mean, of course, that the specific choices made respect it to its full extent. Subsidiarity also arises in the form of the ultima ratio principle, when one examines under this scope the proposed criminal provisions themselves. In this respect, we already have seen that the proposal cannot avoid relevant criticism (see above under 3).

\section{b) Explicit justification of subsidiarity by the European legislator?}

Last but not least, the Commission's proposal gives a convincing justification for intervening with a directive in the field of criminal measures for the protection of the Union's financial interests. According to its explanatory report: “...the Union's financial interests are by nature, and from the start, placed at Union level. As such they are even more "union-centred" than a field subject to harmonisation of rules in the Member States. They are more comparable in form and substance to rules on the Union institutions', bodies' offices' and agencies' self-protection, such as in terms of physical or IT-security........ Only the Union is in a position to develop binding approximation legislation with effect throughout the Member States, and thus to create a legal framework which would contribute to overcoming the weaknesses of the current situation, including in particular the lack of equivalence which is inconsistent with the treaty objectives set out in Article 325 (4) TFEU" ( COM (2012) 363 final, p. 8). However, this justification remains general and does not differentiate between the specific offences. The proposal in no way refers, for example, to the fraud related offences for which the above justification of the subsidiarity principle cannot be taken for granted. This is especially true for the 
offence of money laundering, for which the Union has never explained until now whether it respects the subsidiarity principle by making use of criminal law measures.

\section{On the coherence of domestic criminal justice systems}

\section{a) Undermining or safeguarding the coherence of national criminal justice systems?}

The provisions of the proposed directive are expected to cause problems first of all in Member States that are not familiar with a system of minimum level of penalties threatened by criminal law provisions. This is a fundamental choice that a national legal order should be left to make by itself and in any case national legal orders shouldn't be forced to do that through a directive just for a number of offences and for the sake of European harmonization.

However, even for Member States that are already familiar with this system, it may very well be that the minimum level of six months imprisonment, established in Article 8 for cases of fraud or fraud related offences involving an advantage or damage of at least 100,000 Euros or 30,000 Euros respectively, is higher than the one the national legal orders foresee for the same level of advantages or damages concerning their own financial interests. In other words, setting a minimum level of penalties, the European legislator throws the national legal systems much more easily out of balance, as there is no way to escape this minimum threshold, while such a possibility on the contrary exists as far as the maximum level is concerned, because the latter can be avoided by the judge when selecting the concrete penalty for the conduct to be punished.

On the other hand, under such a European system of setting the minimum levels of penalties additional questions arise: e. g. is the suspending of sentences on parole or the stay of execution for such cases still possible? Can the Member States, which are familiar with a system of deviating from minimum punishment thresholds, still enforce such a system in these cases? Such important questions, triggered by the Commission's proposal, shouldn't be overlooked before adopting a new system of introducing penalties on European level.

\section{b) Horizontal coherence}

Additionally, it should be noted that the Commission's choice for a minimum level of penalties in respect of offences affecting its financial interests leads to inconsistency with the primary law of the EU itself. If one focuses on money laundering, for example, the difference for punishing money laundering acts after a fraudulent conduct affecting the financial interests of Member States is obvious. For the latter, binding minimum penalties set on a European level do not exist, even if the relevant advantage or damage is over 30,000 Euros. The question that arises in this respect is whether such a result can still be in conformity with Article 325 para 2 TFEU, according to which Member States are obliged to protect the Union's 
financial interests as they protect their own. In other words, the Union's choice for its own financial interests contravenes not only the assimilation principle introduced by the TFEU, but it also creates problems of inequality of protection between the financial interests of the Member States and those of the EU, something that was not at all intended by the Lisbon Treaty.

The solution to this problem cannot be found, of course, in adopting the method of binding minimum and maximum thresholds of penalties on a European level as a general tool, because it is manifest that this would create even more problems with regard to the principle of coherence both on a horizontal and vertical level.

\section{c) Explicit justification of the proposed provisions under the perspec- tive of coherence?}

Unfortunately, the Commission's proposal does not contain any specific thoughts or arguments referring to horizontal or vertical coherence, although one would have expected it to do so, particularly because of the new method introduced with the binding minimum thresholds of penalties. Instead of this, one reads about the relevant explanation for choosing the method of minimum imprisonment ranges: "The introduction of minimum sanctions will ensure consistency across the Union in terms of sanctions that apply in any member State for a given type of conduct, with the effect that the Union's financial interests will be protected in an effective and equivalent manner throughout the Union........The introduction of minimum sanctions is consequently considered necessary to ensure that an effective deterrence all over Europe can be achieved". As stressed above, achieving deterrence cannot be obviously the sole or even the main concern of the European legislator in the field of criminal law. His main concern should be the way to combine deterrence with all the other fundamental principles that have to rule his decisions when introducing binding rules for its Member States in an interface system that has to seriously take into consideration both European law and national legal traditions. As already mentioned, over and above the consistency across the Union in terms of sanctions that apply in any Member State for a given conduct, the introduction of minimum sanctions cannot be ensured because the same level of sanctions has a completely different dimension, institutionally and in practice, in the various Member States.

\section{Overall Evaluation}

The above analysis of the rules concerning the criminalization of fraud affecting the Union's financial interests, allows us at this point to draw a general conclusion:

In the proposal for a directive on the fight against fraud affecting the Union's financial interests one can clearly discern the Commission's effort to comply with fundamental principles of criminal law. This is particularly the case with some provisions which are express manifestations of the ultima ratio (Art. 4 para 3 (a), (b)active and passive corruption only for future actions of an official, Art. 7 para 2- 
option for non-punishability of minor offences) and the proportionality (Art. 3- no clause for inferring the intention solely from factual circumstances) principles. However, there are a number of provisions with regard to which the proposal does not manage to actually safeguard such fundamental principles to their full extent.

As has been shown above, significant deficiencies can be detected not only through classical principles of criminal law (: ultima ratio, guilt, the proportionality principle and the principle of legality), but also through the principles of subsiadiarity and coherence, which bear a particular importance in the field of European law. In this sense, the proposal needs further systematic elaboration that would ameliorate its quality with regard to European fundamental principles and the rule of law.

On the other hand, both central axes of the Commission's proposal, i. e. the introduction of a legal instrument that also covers broadly defined fraud related offences, which do not directly violate the Union's financial interests, and the introduction of a new method for setting obligatory minimum thresholds of punishments for their minimum level, are problematic with regard to the Lisbon Treaty provision, which sets the Union's competence for the preventing of and fighting against fraud (Article 325 para 4 TFEU), as well as in respect of the fundamental principles of European criminal law. Thus, further systematic elaboration of the proposal is necessary with regard to its central axes as well.

\section{Recommendations for the Amendment of Specific Provisions of the Proposed Directive}

According to the above analysis, the following recommendations could be made for the amendment of specific provisions of the Commission's proposal:

1. All fraud related offences, apart from those dealing with public procurements or grant procedures (Art. 4 para 1) and the misappropriation of the Union's funds by a public official (Art. 4 para 4) which refer directly to the protection of the Union's property and not to the protection of other legal interests, should not be included in the proposed directive, because -amongst other reasons- they contravene the legal basis chosen for it.

2. Certain articles of the proposed directive should be improved in terms of respecting the ultima ratio principle as follows:

a) Article 3: the European legislator should bind the proscribed omissions that constitute fraud to the prerequisite of a violation of specific obligations, because otherwise criminal liability would extend unjustified to omissions that cannot be held equivalent to acts.

b) Article 4 para 1: the suitability of the proscribed conduct to cause a possible danger for the circumvention or skewing of the eligibility, exclusion, selection or award criteria of a public procurement or a grant, should be added as an actus reus element and the aim to damage the Union's financial interests should supplement the mens rea. 
3. Some other provisions also need to be improved, in order to respect the guilt and proportionality principles. For this purpose, it would be advisable that the European legislator:

a) reduces the penalty foreseen for the fraud related crime described in Article 4 para 1, which refers to public procurements and grant procedures, as this conduct can never be equated to fraud,

b) (in the case of maintaining the provision of Art. 4 para 2) adjusts the penalty foreseen for money laundering to a level that would not be higher than that of fraud (Article $8,2 n d$ phrase) as well, and

c) reconsiders the method of binding minimum thresholds of penalties (Article 8 para 1), which causes more problems that those it is meant to solve.

4. Breaking loose from the method of binding minimum thresholds of penalties (Art. 8 para 1) would also help to better serve the principle of coherence, which plays a central role in the framework of European law.

5. The following changes could help in order to comply with the lex certa requirement:

a) Article 3: the description of fraud should be made concrete by crossing off the broad and vague reference to acts or omissions relating to the use or presentation of documents etc. Instead of this, fraud should be simply defined as "any act or omission in violation of a specific obligation, constituting: (i) the use or presentation, (ii) non-disclosure of information, (iii) the misapplication of liabilities or expenditure."

b) Article 4 para 3: the description of corruption should also explicitly refer to a bribery behaviour which is meant to lead to an act or refraining from acting of an official against his duties.

6. Last but not least it would be wise to ensure the proposal produces substantial reasons, related to its concrete provisions, for respecting the proportionality principle as well as the principle of coherence.

7. The same (as in no 6) is advisable for safeguarding fundamental rights, as it is not sufficient to simply list those that can be affected or protected from the specific provisions without any further substantiation. 